\title{
REGIONAL INSTITUTIONS AT THE DOORSTEP OF POST 2020 COHESION POLICY - STATUS REPORT FROM HUNGARY
}

\author{
Balázs SIMÓ $^{\mathrm{a}}$, Tamás GORDOS ${ }^{\mathrm{b}}$, Viktória JÓZSA ${ }^{\mathrm{c}}$ \\ ${ }^{a}$ Hungarian Development Center, 1027 Budapest, 14-24 Horvát str., simo.balazs@mfk.gov.hu \\ ${ }^{\mathrm{b}}$ Pro Régió Agency, 1146 Budapest, Hermina út 17., gordos.tamas@proregio.hu \\ c Nord Consult Ltd. 1106 Budapest, 45 Jászberényi Road, viktoria.jozsa@gmail.com, corresponding \\ author
}

Cite this article: Simó, B., Gordos, T, Józsa, V. (2018). Regional Institutions at the Doorstep of post 2020 Cohesion Policy - Status Report from Hungary. Deturope, 10(3), 14-32.

\begin{abstract}
'My Region, My Europe, Our Future' (EC, 2017). This is the main message of the Seventh Report on Economic, Social and Territorial Cohesion. In the post 2020 period, the European Commission continues to focus on the compliance with challenges of the knowledge-based economy, and in parallel, stands for a strong territorial approach and increased synergy and coordination of the connected sectoral financial means and measures. The question is if Member States are ready to face the challenges that are specified in the report, such as digital revolution, globalisation, demographic change and social cohesion, economic convergence and climate change. In connection to this basic question, our paper aims to provide an overview about the evolution - rise and fall - of the Hungarian regional level (NUTS2) institutions with a strong emphasis on the state-of-the art, especially regarding administrative capacities. Desk research focused on the era between 1990-2015, while empirical research - in the form of a questionnaire - was conducted in 2017 and 2018 amongst former employees of the former regional development agencies. As there are no institutionalized actors at regional level in Hungary responsible for the implementation of Cohesion Policy any more - with the exception of Central Hungary, that is currently under re-formulation - we hypothesize that former(?) regional development professionals as individuals could play an important role in the preparations for the post-2020 financial period. In case they are involved...
\end{abstract}

Keywords: Regionalism, Post-2020 cohesion policy, Public administration, Capacity development, Networking

\section{INTRODUCTION}

The system change in Hungary, similarly to other CEE countries, brought significant changes in many fields of politics, public law and the economy. The overall political climate was in favor of decentralization and seemed to follow western trends at the beginning. The rapid change regarding the factors of competitiveness, as services became the major driving forces instead of production, also generated the need for structural changes in territorial governance as well. Even though the Local Government Act passed in 1990 created 3000 local municipalities but failed to delegate the necessary resources to secure their proper functioning. Soon it has become obvious that the new law increased the municipalities' vulnerability instead of giving them self-determination (Pálné Kovács, 2007). 
Consequently, the territorial midlayer fell under the influence of the line ministries' deconcentrated organs. So even though the restructuring of the territorial governance model was done, the conditions were not set for the long-term functioning (Pálné Kovács, 2015). Certainly, the territorial development institutional system was also affected by these tendencies aiming towards de-concentration.

In the study, we provide a short overview on the theoretical background and the data and methods. Then, the results of the desk research are presented focusing on institutionalization and quantitative indicators from the 2009-2015 period. The empirical survey completed in 2017 and 2018 will provide an in-depth analysis about what has happened to the former employees of the NUTS2 level public administration and will examine whether the concept, principles and methodologies of regionalism and cohesion (regional) policy have survived in Hungary through the professionals as transmitting platforms. Finally, conclusions are drawn for policy makers and practitioners with the aim to exploit these 'hidden' but precious capacities in the preparation process for the post-2020 period.

\section{THEORETICAL BACKGROUND}

There are some interesting recent studies available on the effectiveness and impact of Cohesion Policy in the CEE countries, however these studies either focus on the utilisation of

EU funds and absorption capacity with a quantitative methodology (Pálmai, 2014), or combine empirical results and statistical data in order to conduct cross-country comparison and identify different patterns and trajectories from the past (Nagyházi, 2015).

Other authors have published works on Central and Eastern Europe about regional dynamics (Palermo and Parolari, 2013), regional development agencies (Halkier et al., 1998), decentralization and transition (Kirchner, 1999) and there are some country-specific essays also for the Czech Republic and Slovak Republic (Nemec \& Matejová, 2014), Poland and the Czech Republic (Yoder, 2003), and other works on horizontal partnership and patterns of subnational governance in Poland, the Czech Republic and Hungary (Dabrowski, 2013), without being exhaustive. When taking a look at Visegrad countries, as a wider geographical scope, we can find different practices for decentralization and regionalization. Slovakia and the Czech Republic are often characterized with a decentralized unitarian model, and Poland with a regionalized one, while Hungary has a unitarian structure (EGTC, 2009). It can be stated that various territorial self-government and regional development systems have emerged in the V4 countries as answers to the requirements of place-specific development of EU Cohesion Policy. According to research results of a study that completed a V4 level 
comparison on regional development trends and institutional environment, the Czech Republic could be characterized with a learning process between 2004 and 2006; and a fullscale programme implementation between 2007 and 2013 with an important and growing role of regional self-governments. The territorial differences are the least significant compared to other V4 countries. Slovakia had not implemented ROP in its first cohesion period and has been implementing a single ROP in 2007-2013. Its territorial disparities are among the largest in the V4 group and Eastern Slovakia is still falling back visibly. As regard Poland, in spite of growing regional disparities between 1995 and 2009, recent development processes show relatively stable development disparities apart from a still significant difference between the capital region and the rest of the NUTS II regions (Nagyházi, 2015). It is interesting to point out that while the referred author (using a rather quantitative methodology) recently labelled the Czech Republic and Poland as good examples for consensus-based decentralization processes, Dabrowski (on the basis of empirical research) stated in 2013 that regional programming was undermined by strong central control in these two countries (Dabrowski, 2013). Finally, the regional processes in Hungary from PHARE to Smart Specialisation were also thoroughly analysed and presented in a recent study (Józsa, 2016). The current study is unique in its research focus that examines the potential to exploit the cumulated knowledge, experience and approach of regional development professionals (former colleagues of RDAs) in the implementation of Cohesion Policy during the next programming period, despite the foregoing dissolution of the regional institutional system.

\section{DATA AND METHODS}

In order to have an in-depth understanding about the institutional background and the context in which Hungarian agencies have had to perform, a secondary research was conducted about the evolution of the post-socialist Hungarian territorial development. An extensive primary analysis was also done about the most important Hungarian measures and legislative files together with their modifications, which regulated or still regulate territorial development. Nevertheless, in order to have the proper insight to the agencies' portfolio and periodically changing workload, not only data published by national or regional organisations was gathered, but also internal desk research was conducted in case of the agencies' successors and the line ministries, playing a key role in EU fund management. To elaborate the future prospects, the authors relied upon the broad theoretical literature on regional development and knowledge-based economy. 
The empirical research was conducted in August-September 2017 in the form of an electronic questionnaire amongst the former employees of the dissolved (6) and the functioning (1, Central Hungary) regional development agencies (RDAs). As a predecessor, a 'regional coordinator' was designated and a prior contact was established, in order to (1) reach as many former colleagues - recently working at numerous and very diverse organisations - as possible, and (2) increase the efficiency of the filling and to enhance the response rate. There have been some regions where specific social media groups are still existing and operating and there were others, where only personal contacts sustained.

As a methodological tool, snowball sampling was applied and we both sent out the equestionnaire to the private e-mail addresses of the target group and asked the regional coordinator to post the link of the questionnaire on the common group's profile. The sample involved the colleagues ever worked for any regional development agency or council on the basis of either an employment contract or a personal work assignment contract. Based on experts' estimate the whole size of the population (total number of the group) is approximately 1,000 people, so the ratio of the respondents is $10 \%$ of the total population (95 received questionnaires) that is relatively high. We do not claim our research as representative, though.

When defining the tool for the empirical research, we took into consideration the characteristics of the sample (young-mid-aged, digitally totally literate, using ICT tools in their everyday work) and we paid special attention to secure anonymity, that was a very important aspect, and in the same time, a crucial expectation from the target group. The questionnaire included several thematic blocks; as sociographic characteristics, experience with RDA, recent employer and work experience, future concept and relation to regionalism. We applied closed and open questions and scales both, and the filling of the questionnaire took about 30 minutes.

Additionally, semi-structured interviews were also carried out in May-July 2018 with professionals having at least 10-year long operative experience at either one of the RDAs or any of the line ministries or governmental organs having fulfilled the Managing Authority role regarding the management of the territorial OPs. These interviews had a focus on defining the added value of the Hungarian RDAs. Questions were raised about the room for manoeuvre given to the agencies within the territorial development system and the policy set by the central government. Targeted conversations were run about the specific features and characteristics of the RDAs to gather information and expert opinions about the differences between the old and the current operative level setup of the territorial development system. 
Simó, B., Gordos, T, Józsa, V.

\section{RESULTS AND DISCUSSION}

\section{The 90ties: hindering circumstances for regional development agencies' capacity building}

In the followings, we present the results of the desk research. In theory, subnational stakeholders could take part in several ways in the fund management pipeline (Bachtler and McMaster, 2007). Although every post-socialist candidate countries' regions were involved to a certain extent in the planning and implementation activities of the Operational Programmes, the territorial institutions were proved to be weak in comparison to the line ministries and governmental organisations of the traditionally centralized countries. It was especially true to the countries without democratically elected assemblies, not having regions with political legitimacy. The lack of regional governments, their fragmentation (Slovenia, Latvia) and inadequate capacities (Czech Republic) also played important role in the abovementioned tendencies. Besides, Blazek and Vozáb (Blazek and Vozáb, 2006) pointed out that these countries were missing those experience, know-how, mechanisms and forums that could have served as a basis for a true dialogue for territorial players. The Hungarian territorial stakeholders were also struggling with these problems.

One major significance of the Act on Territorial Development (1996) was to incorporate the EU's development-statistical layers into the Hungarian legal system. Since there were no strict rules to be applied, the territorial unit that should be defined as a region had become an issue of debate among the parliamentary parties. As a political compromise, the setting up of a NUTS 2 region became an option and not an obligation for the NUTS 3 level counties. County level (NUTS 3) development councils (CDC) had become the corner-stones of the Hungarian regional development system. Not even the regions' exact territories were defined by the first version of the law. This brought unpredictability, while also eroded the regions' identity. Upon that, the Act defined regions as planning and statistical territorial units, that undermined the opportunity for them to become part of a multi-level governance (MLG) system on the long term. With this decision, the Hungarian Parliament created an additional layer in the territorial governance without any executive or legislative power.

Even though the act did not grant democratic legitimacy and executive power to the regions, it empowered the County level (NUTS3) Assemblies to create Regional Development Councils (RDCs). Their tasks were to draft and implement regional development strategies. A majority of the members were delegated by the counties, municipalities and different chambers. At the beginning, the territorial stakeholders outnumbered the centrally delegated ones. 
On the other hand, the low representation of the county level indicated from the beginning, that the Hungarian territorial development structure was reorganized in a compact, thematic policy- and not territorially-driven way. The region, in comparison to the other territorial levels, became the weakest one.

Just like the establishment of the regions and the TDCs (territorial development councils), the setting up of the regional development agencies (RDAs) was also optional. The act did not specify well enough their financial background, or their legal and professional requirements. These shortcomings caused significant difficulties in their capacity building (Pálné Kovács, 2003):

- Since the councils were deciding about their size, structure and operative circumstances, they were heterogeneous from qualitative and from quantitative point of view.

- Scarce governmental resources hindered predictability at institutional and employer level as well.

- The financial problems were also hindering the capacity building on such a high extent that in some counties they were fulfilling their tasks as part of the county bureaus.

The major hardship for the institutions was that they had no decision-making power over the state granted decentralized territorial development funds. Until 2001 the allocations were done either by the line ministries or by the counties (Nemzeti Fejlesztési és Gazdasági Minisztérium, 2009, 16. p.).

As a conclusion, it can be stated that the Hungarian governments were not willing to give up their decades-long dominant position when the question of the MLG were raised. Only the accelerating pace of Hungary's EU accession could have brought a slight change. Although the Act on Territorial Development was modified in 1999, and the creation of the RDCs and RDAs became obligatory, the change brought even a more centrally organized territorial development structure. Not only did the centrally delegated members of the RDCs outnumber the territorial ones, but majority vote, instead of the qualified one, was also applied on more issues. Overall it meant that the Hungarian territorial development legislation failed to introduce a well-established decentralized structure, with strong and democratically legitimized regions in its forefront. So, the regions and their organizations were dedicated to fulfill only technical functions (Pálné Kovács, 2016, pp. 76-80.).

Constantly strengthening intermediary body role

Keeping the above described institutional settings in mind, it should not come as a surprise that until Hungary's EU accession, the RDAs' tools could be categorized as traditional ones. They were fulfilling the following tasks:

- coordinative role (mainly planning and project generation); 
- administrative tasks related to the distribution of state aids and Pre-Accession Assistance funded grants (mainly the Phare programme).

As decentralized funds for regions granted by the state were doubled between 2003-2006 (Rechnitzer, 2002), and by accessing the EU, Hungary became eligible for approximately 400 million EUR funding from the Regional Operational Programmes (ROPs). Thus, the central government's supervision on RDAs got even stronger. Instead of territorial entities, the National Office for Regional Development, a central government body supervised by the Cabinet of the Prime Minister, was nominated as the Managing Authority (MA) for the ROPs. The RDAs only acted as Intermediary Bodies in the implementation structure, in line with Commission Regulation 438/2001. Their main tasks and responsibilities were the following technical, operative ones:

- dissemination tasks regarding the call for proposals;

- registration of the submitted applications,

- formal and quality assessment of the project proposals;

- advisory desk for the potential beneficiaries in case of project generation;

- preparation of strategic development documents on the regional scale;

- audit activities in case of the implemented projects;

- dissemination exercises in relation of the OPs' achievements.

These tasks were carried out throughout the whole programming period by the close supervision and control of the MA (Miniszterelnöki Hivatal, 2003). The Managing Authority only assessed the performance of the RDAs according to the implementation of the ROPs, since their major income came from the Technical Assistance (TA) budget of the above programmes.

Although they have become substantial part of the EU implementation pipeline, the centralized circumstances were rigid and did not grant them any decision-making power or room for widening the scope of their activities and portfolio. It meant that according to the criteria system set by Halkier and Danson (1996) in the late nineties, the Hungarian RDAs could not have been defined even in the new century as model or potential RDAs:

- Although from the legal point of view they were separate entities but were under the close supervision and control of the central government.

- They were operating by the means of traditional tools. Their consultancy services did not cover assistance in areas such as management, business environment or vocational trainings.

- Never got the task and chance to deal with financial instruments besides the traditional grant schemes. 
That doesn't mean that the agencies or their councils would not have had their internal agenda and strategic outlook on how to improve their capacities and widen not only their tools but also the area of expertise and operation. Some RDAs have been active in international cooperation projects (West Transdanubian RDA and North Great Plain RDA), others launched consulting services and spatial planning activities (Pro Régió). Taking the annual work programme for 2004 of the West-Transdanubian Regional Development Council as an example, it clearly states the willingness that the RDAs should cover other tasks than the IB (Intermediary Body) ones:

- strategic planning;

- programme and project generation;

- inter- and intraregional institutional coordination;

- creation and maintenance of international relations;

- economic initiatives such as cluster and industrial site development, cooperation with regional entities in order to foster local innovation.

Only the traditional and conventional tasks regulated in the act would have required much more financial resources for the agency then the amount (EUR 140,000) it received from the state budget in 2004. The low level of state financial subvention clearly indicated the need for the agencies to generate income from other sources than the state budget or the TA (technical assistance) budget of the OPs. Hence this would have had required a clear government policy, with support on capacity building for fulfilling multi-tasking capabilities, and dedication of a strategic role and decision-making power on regional development issues, while providing them with the necessary funding.

However, the tendencies went right to the opposite direction. By having the 2004-2006 EU budgetary period closed, the Hungarian government nominated the state organ National Development Agency (NDA) to be the responsible institution for the harmonization of the regional and line ministerial development policies. It also acted as the MA for the ROPs of 2007-2013.

Above all, as it was written on page 102 of the National Development Plan 'The professional and governmental control over the RDCs' decisions is granted by the government presence in the councils'. The final responsibility for the implementation of the 2007-2013 territorial OPs was laid in the hands of the central government, just like that of the thematic OPs.

On one hand, the hierarchy of the previous programming period was reinforced between the regional and central stakeholders. On the other hand, these decisions pulled the RDCs and the RDAs into a more technical and administrative area in the system of the EU funds' 
distribution mechanism (Gordos, 2009). Hence, the above governmental steps guaranteed a comfortable status and financial stability for the agencies in the mid-term. (They managed to make an overall revenue of almost 2.2 million EUR (Baker Tilly Hungary, 2014) between the year 2007 and 2010.) The IB tasks also required additional capacities from the institutional side, in a way that distracted the vast majority of managerial and operative resources. Tab. 1. indicates the rapid growth of the employees from the beginning of the 2007-2013 period while Tab. 2. shows the exponential growth of IB workload in case of the South Transdanubia Operational Programme.

Table 1 Hungarian RDAs personnel (2007-2010)

\begin{tabular}{|l|c|c|c|c|}
\hline & $\mathbf{2 0 0 7}$ & $\mathbf{2 0 0 8}$ & $\mathbf{2 0 0 9}$ & $\mathbf{2 0 1 0}$ \\
\hline Employees of RDAs (in person) & 523 & 710 & 830 & 898 \\
\hline
\end{tabular}

Source: data of the Prime Minister's Office

Table 2 The Main Implementation Indicators of The South Great Plain Operational Programme (2009 and 2013)

\begin{tabular}{|l|l|c|c|}
\hline \multicolumn{2}{|c|}{ Task } & $\mathbf{2 0 0 9}$ & $\mathbf{2 0 1 3}$ \\
\hline $\begin{array}{l}\text { Registration/submitted projects } \\
\text { (number, applied amount) }\end{array}$ & number & 1873 & 3540 \\
\cline { 2 - 4 } Granted projects (number, sum) & M EUR & 886.8 & 1809.72 \\
\hline \multirow{2}{*}{$\begin{array}{l}\text { Contracted projects } \\
\text { (number, sum) }\end{array}$} & number & 607 & 1550 \\
\cline { 2 - 4 } & M EUR & 48.49 & 882.86 \\
\hline \multirow{2}{*}{ Payments (number, sum) } & number & 466 & 1535 \\
\cline { 2 - 4 } & M EUR & 240.14 & 866.07 \\
\hline $\begin{array}{l}\text { Closed projects } \\
\text { (number, sum) }\end{array}$ & number & 337 & 1426 \\
\cline { 2 - 4 } & M EUR & 80.99 & 644.07 \\
\hline
\end{tabular}

Source: Annual Reports of the South Great Plain Operational Programme, 2009 and 2013

The overwhelming workload and the engaged resources for the IB tasks did not leave room for additional tasks or services. The sources of income had become even more one-sided. Fig. 1 shows two RDAs' (South Transdanubian Regional Development Agency (DDRFÜ) and Central Hungary Regional Development Agency (Pro Regio)) income ratio generated by the business activities compared to the overall revenue. It can be seen how much the IB tasks squeezed out other functions, especially during the periods of rapid growth (2004-2006, 2007 2010). 
Figure 1 Income Ratio Generated by The Business Activities Compared to the Overall Revenue of Pro Régió and DDRFÜ 2000-2010

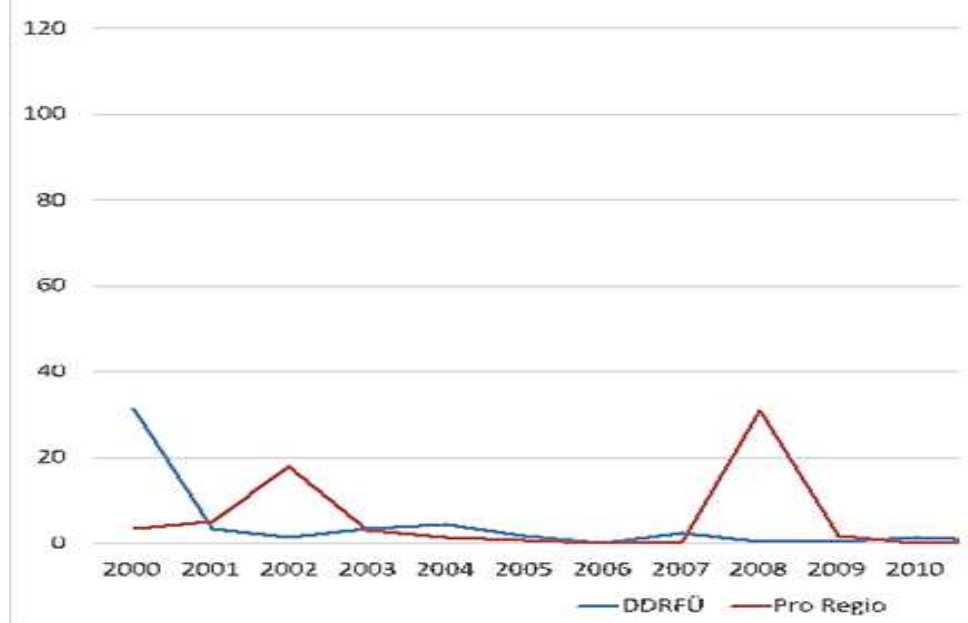

Source: Annual Reports of DDRFÜ and Pro Régió

\section{Further centralization and dismissal}

From 2010 the newly entered national government started a general centralization process on state level that also had its effect on the territorial development structure. In 2012 the government took further steps to secure its control over the RDAs and prioritize their IB role by modifying the Act on Territorial Development: the RDCs were dismissed and the RDAs ownership was transferred to the state. By the beginning of 2014, the NDA was also dismissed and the MA role of the ROPs was delegated to the Ministry of National Economy, while certain coordinative roles for the absorption of the EU funds were delegated to the Prime Minister's Office. Having lost many ties for the territorial stakeholders and being controlled by the highest-level organs of the state administration, the RDAs duties were prioritized by the ministries and the absorption rate of the EU funds was among the top of the list. As an illustration Tab. 3 shows that the growth of the income the RDAs received for the IB tasks almost grew six times within seven years (2007-2013).

Table 3 The RDAs income received for their IB role in 2007-2013

\begin{tabular}{|c|c|c|c|c|c|c|c|}
\hline \multicolumn{1}{|c|}{} & \multicolumn{2}{|r|}{ data in EUR } \\
\hline & $\mathbf{2 0 0 7}$ & $\mathbf{2 0 0 8}$ & $\mathbf{2 0 0 9}$ & $\mathbf{2 0 1 0}$ & $\mathbf{2 0 1 1}$ & $\mathbf{2 0 1 2}$ & $\mathbf{2 0 1 3}$ \\
\hline IB income & 3471366 & 7785050 & 11368866 & 15795723 & 16308310 & 16746370 & 18839386 \\
\hline
\end{tabular}

Source: data from the Prime Minister's Office

Although there was no loss of ROP funds due to low absorption rate, the centralization dynamics did not slow down by the end of the previous EU budgetary period: the RDAs Service Level Agreement contracts, that regulated the IB tasks, were not prolonged by the Ministry of National Economy at the end of 2015. Upon that, the Hungarian State Treasury 
was nominated as an IB for both territorial development OPs of the new budgetary period (2014-2020). The ownership rights were transferred back to NUTS3 level counties. Lacking the region as a territorial layer (regulatory background) and any financial resources coming from the state, the counties (except for Pest County) decided to dismiss the RDAs and try to build up their own separate capacities for territorial development.

\section{Experience at the RDA}

From this point, we present the results of the empirical research based on a questionnaire. Regarding the sociographic characteristics of the respondents, the gender distribution was balanced (females: 51\%, males: 49\%), while the age distribution was very interesting, as more than $65 \%$ of the respondents was born between 1971-1980. More specifically, more than 55\% of the respondents was born between 1974-1980. An additional 26\% was born between 19811990 , so it can be concluded that the huge majority of professionals was in its 20 s and 30 s while being employed at the RDA.

At first, we examined the territorial distribution of the respondents, if they stay at their 'host' region, or if there was a significant brain drain effect towards other regions. It is a positive result from the aspect of territorial cohesion, that most of the professionals could stay and continue their activities in their home region after the fall of the RDAs $(78 \%$ works in the same settlement/county). Some brain drain effect can be detected towards Budapest and the national level sectoral ministries $(6.6 \%)$, that is in line with the overall national tendencies in other sectors, and there was also some international migration $(2.2 \%)$.

As regards the former position at RDA, the majority (61\%) of the respondent was a colleague of the Intermediary Bodies (IM), about $6 \%$ was working in regional programming and planning and $30 \%$ of the respondents was a middle- or strategic manager.

It should be highlighted, that a high proportion (30\%) was working as international project manager that underlines the very strong international network and embeddedness of the RDAs.

Most of the respondents were graduates or young professionals, for whom the RDA was the first or second employer. Complementary to age distribution, this fact is also supported by the research result about the period and length of employment at the RDA. More than $82 \%$ of the respondents have been working for more than 5 years at the RDA, including more than one-third of the sample working for more than 10 years at the RDA. This result is outstanding in the light of the fact that the 'lifecycle' of the RDAs was 15 years in general, mostly between the second half of the 1990s to 2015. The following graph illustrates well that (Fig. 2) the staff at the RDAs was very stable during their operation period, and a continuous scaleup was typical. It lasted until 2015, when a sudden collapse could be experienced, without prior subsidence or a consciously planned cutback. 
Figure 2 Distribution of Respondents based on Employment Period at RDA

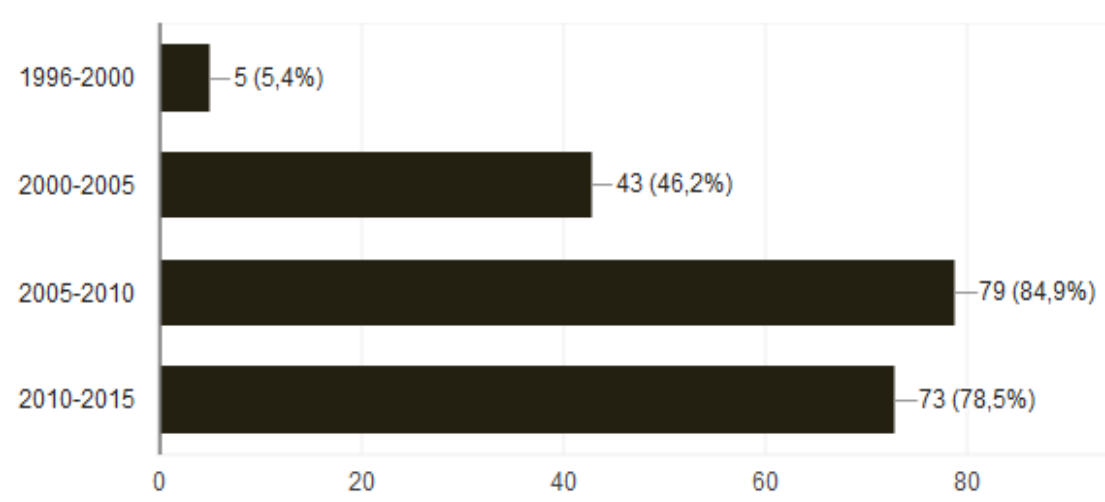

Source: own construction based on empirical research, 2018

As reason for exit from the RDA, 65\% of the respondents specified the abolition or restructuring of the RDAs, $17 \%$ received a better job opportunity and 3\% departed to maturity leave. Another $6 \%$ defined other causes, for example burn-out, narrowed programming duties, escaping forward, politics, new leadership, or the irreconcilable difference in values. Only $1 \%$ specified the establishment of an own consultancy company as the cause of exit.

We aimed to figure out what factors attracted these young, well-educated people to the RDAs as workplaces, and we concluded that the major motivation was the interesting work in connection to the European Union. At the second and third rank, the respondents specified the opportunity to continuous professional development and step forward together with the involvement in decision-making and regional development. The stable, well-predictable income was mentioned only at the fourth place.

Thus, we may conclude that the former RDAs staff was young, committed, strongly motivated, agile, dynamic with a strong responsibility towards shaping the future at regional level. The number and composition of the employees was stable, well until the almost full elimination of the regional institution system (Table 4).

Table 4 Motivations of Respondents for Starting an Employment at RDAs

Main motivation of starting an employment at the RDA

interesting tasks in connection to the EU

opportunity to continuous professional development and step forward

involvement in decision-making and regional development

stable, well-predictable income

opportunity to use the previously learned foreign language

networking, other colleagues, friends were working there

opportunity to travel a lot

other

Ratio (\%)

Source: own construction based on empirical research, 2018 


\section{"All that the RDA could provide..."}

In the next part of the questionnaire we were curious about what exactly these young professionals could have received from the RDAs during their employment period, how did they see their former employers, and if they could recently apply/adapt any of the learned routines or knowledge in their everyday life. At first, we applied a scale from 1-10 (1: very bad, 10: excellent) in order to measure the content of the respondents with the RDAs, whereas more than $92 \%$ positioned their years spent at the RDA between $8-10$, meaning very good or excellent. It should also be highlighted that there was no value below 5 even from the most critical respondents.

As a second question we aimed to specify the experience, practice and knowledge that the respondents acquired during their years at the RDAs. The most common features (with a minimum $60 \%$ of respondents mentioning them) were 'professional experience', practice, 'principles and values connected to EU regional (cohesion) policy', 'professional network' and 'working culture'. About half of the respondents mentioned the conflict resolution techniques, communication with beneficiaries, theoretical and practical knowledge about strategic programming and the trainings and study tours. Answering one of the basic questions of the empirical research, it can be concluded that the RDAs provided a very diverse knowledge- and skill portfolio to their employees.

Going one step forward and arriving to the present, we analysed whether the previously acquired knowledge has been dissolved with the restructuring of the subnational institutional framework, or if it could survive and was spread over with the transmission of individuals, the former RDA colleagues.

For this purpose, we asked the respondents to specify the knowledge, competences and skills that they acquired at the RDA and still utilise at their current workplaces. Research results provided clear evidence that there is a strong overlapping between the previously acquired and the currently utilised skill and competence portfolio, thus, the components of regionalism and the principles and methods connected to cohesion policy do survive and continue. The range of the organisations currently employing the former RDA colleagues has been significantly widened, and it is not confined to public administration any more. Several beneficiaries, including economic actors, such as large companies and small- and mediumsize companies, together with civil sector actors also appeared. One additional aspect occurred in the answers, that was the 'international approach and mindset' and openness.

Regarding the first three words that come into the mind of the respondents in connection to the RDAs, the most common answers were: professionalism, teamwork, development and progress, region, partnership, cooperation, decentralisation, fiends, competence, politics and 
Europe. It is important to highlight that - with the exception of one or two excessively negative terms - the specified expressions were strongly positive.

\section{'Where are You, Old Friends?'}

In the next block of the questionnaire, we examined the current position and workplaces of the former colleagues, if the relocation was hard or smooth, and what are the main differences between the RDA and the current employer. About half of the respondents were 'absorbed' by the consultancy sector (24.7\%) and the county (NUTS3) level institutions (23.7\%). Adding up to these the national (11.8\%) and local (4.4) governments and some regional level institutions (9.7\%), we are speaking about $75 \%$ of the former RDA employees working still in the field of territorial (regional?) development. Those working in their own companies (14\%) or at large enterprises $(5.4 \%)$ have clearly changed side; they support the beneficiaries of the cohesion policy. A relatively high ratio $(10.8 \%)$ has transferred to higher education institutions, for which the high number of $\mathrm{PhD}$ and MBA degrees formed a sound basis (Fig 3).

Figure 3 The Distribution of Respondents based on Current Workplace

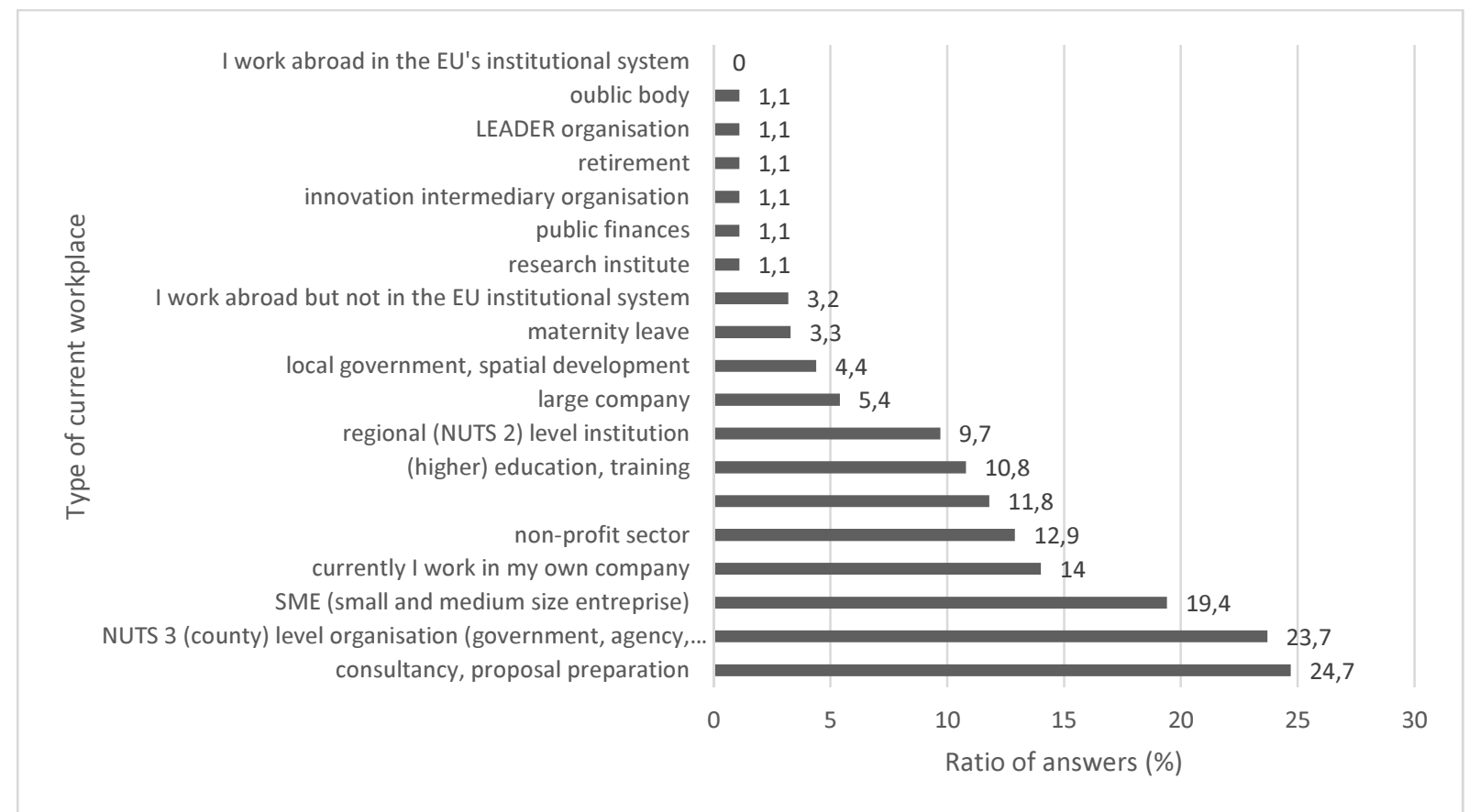

Source: own construction based on empirical research, 2018

Regarding the smoothness of the transition, the up-to-date and highly competitive work experience, competences and professional network clearly advanced the re-positioning. More than half of the respondents (52.2\%) found a new job through friends and reference by connections, while about a quarter (24.4\%) though advertisements and head-hunters. About $11 \%$ answered that they established an own company. If we compare this data with the causes 
of exit, we see a tenfold difference. The justification is that while the cause of the exit was not the setting up of an own company, it has become the consequence of it. Thus, these companies could be also considered as 'forced' entrepreneurs. The ratio of the respondents who were relocated to the successors of the RDAs in direct line was only $7.5 \%$.

The pace of the transition was also quick, as about $70 \%$ of the respondents found a job immediately, $20 \%$ within one or two years, and less than $10 \%$ is retired or on maternity leave.

When asking the respondents to compare their previous (RDA) and current workplace, $39 \%$ answered that there is no significant difference, $37 \%$ preferred the RDA and only $15 \%$ preferred the current workplace. Some typical answers regarding the specific differences were the transition from the supply to the demand side of cohesion policy; the difficulties of the repositioning and the difference between the former resource-efficient and the current inefficient system; the characteristics of the market- and economic environment with special respect to the international context and the economies of scale; the quality of the workplace and the value-added; the differing territorial level and the current deconcentration versus former relative decentralisation; and the larger freedom and widened competence area that goes along on the other hand with larger personal and financial responsibility.

\section{Future Prospects and Relation to Regionalism}

In the last chapter of the questionnaire, we focused on the future prospects of the respondents, and their relationship to regionalism (Fig. 4).

Figure 4 Relationship of the respondents with regionalism

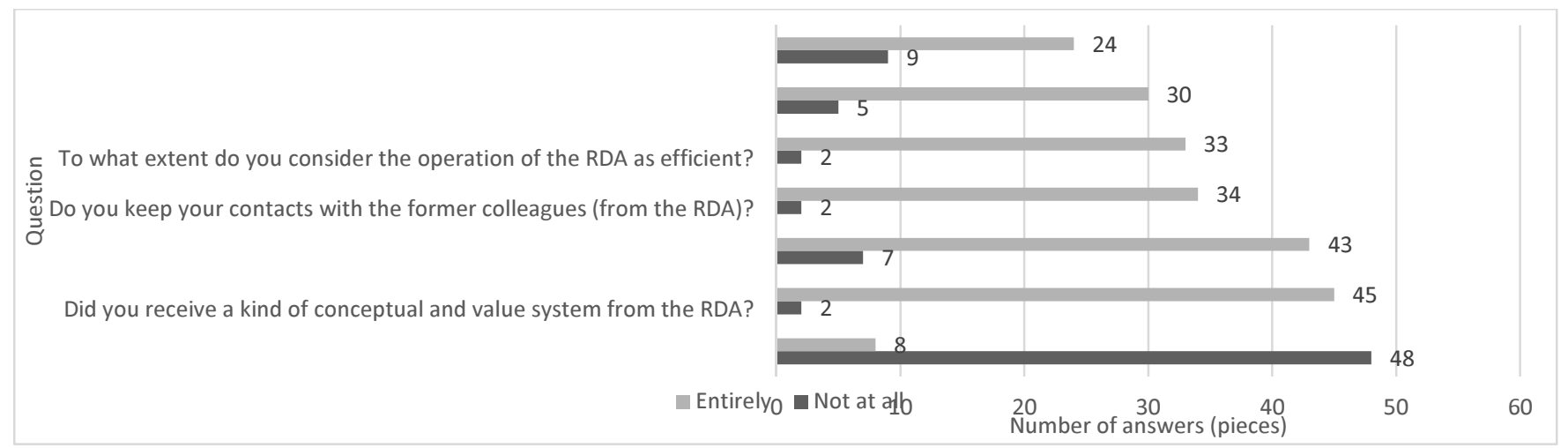

Source: own construction based on empirical research, 2018

It can be summarised that about half of the respondents stated that they received a conceptual platform, and values from the RDA and would happily go back to the RDA if there was a way back. One third of the respondents were influenced by the lessons learned at the RDA when 
selecting the new job, and more than a quarter still apply in their everyday routine the concept and values of regionalism and the EU, at their current workplace.

Although more than half of the respondents considered recent processes as not at all pointing to the direction of decentralisation, a significant majority, $83 \%$ indicated that they are interested in a social platform where they can contact former RDA colleagues. Almost $60 \%$ of the respondents also provided their private e-mail addresses for the purpose that is a very high percentage, with special respect to the sensitivity of the topic. More than $84 \%$ considered the research interesting and useful.

Finally, when we asked the respondents to specify the first three word coming into their mind about regionalism, the most commonly mentioned terms were: decentralisation, development, cooperation, local, RDA, partnership, opportunities, EU, subsidiarity, countryside and territory.

\section{CONCLUSIONS TO POST 2020}

Recently we are experiencing the debates about the post-2020 financial period, and the challenges of the Cohesion Policy.

One major driving force behind these discussions is the knowledge-based economy, which also shapes the characteristics of the new generation RDAs. The access for information and knowledge has become the driving factor of competitiveness. This tendency is constantly overruling the previous theories in relation to the utilization of the endogenous potential of the different territories (Crevoisier \& Jeannerat, 2009). The new challenges of the local and global environment questioned not only the discipline of the territorial development as such, but the RDAs' concepts as well (Cooke \& Laurentis, 2010).

In the near future those geographical units will be able to enhance their competitiveness which are not only able to mobilize, but also combine and develop the knowledge gained and internalized from outside. So, the challenge of nowadays is to establish and maintain such institutions that possess the tools. The combinative nature of knowledge-dynamics and innovation require the presence of such institutions which can guarantee cross-sectoral connectivity. RDAs seem a good basis for acquiring new sets of tools because they already have a kind of self-governing and coordinating capability that enables them to autonomously deal with complex problems. Governments and agencies have to play a key role in the establishment and the maintenance of such linkages. Halkier (2012) also highlights the tendency that nowadays the agencies' portfolio related to grant or fund management are shrinking in comparison to the delivery of their institutional and informational resources as a 
service. Taking into account what has been mentioned above, it can be concluded that the tendencies are proving the future necessity of well-financed and politically strongly supported territorial development agencies. As a contrary, previous Hungarian governments imposed constant centralization on the development institutional system and are lately dismissing the agencies.

So, it is a main question if the knowledge and competence accumulated in Hungary during the former programming periods, starting from our EU accession in 2004, is wasted away, or if it is efficiently and innovatively exploited by the policy makers. The regional level (NUTS 2) institutional system and public administration formally does not exist anymore in the country, the regionalisation experiment is failed. It is still not clear whether the 19 county level (NUTS3) municipalities and their development companies will be able to fully take over the tasks of former RDAs, and if they could become the driving forces of subnational development in Hungary. Based on the findings of the semi-structured interviews, the majority of the interviewees (especially those still working in the governmental sector) are very sceptical about that. Not only decision-making has become even more centralized, but they see counties as week actors. They describe the IB role of the State Treasury rather as an authority than a mediator with a tutoring attitude towards the applicants and beneficiaries.

According to them, the current institutional setup and hierarchy do not leave enough room for the flexibility that is required for efficient and result-oriented EU fund management. Above all, in parallel with further centralization, the issue of territorial development is not constantly in focus anymore, but follows the cycle of EU programming periods. On the other hand, the concept, values and principles of the EU and Cohesion Policy still exist and survive through the transmission of professionals, the individuals once working at the abolished regional development agencies and councils. Once upon a time, there was a regionalisation attempt in Hungary, we can say.

The real question is if - in the era of digitalisation and networks - institutionalised organisations are the factors that really matter, or if the community of professionals can be strong and socially coherent enough, and the government can be smart enough, to find a mutually beneficial method to collaborate for Our Hungary, Our Europe and Our Future.

\section{REFERENCES}

Bachtler, J., \& McMaster, I. (2007). EU Cohesion policy and the role of the regions: investigating the influence of Structural Funds in the new member states [Pdf]. 
Glasgow: The University of Stratchclyde. Retrieved from http://strathprints.strath.ac.uk/7811/ (16.05.2018.)

Baker Tilly Hungária Könyvvizsgáló Kft. (2014). A Nemzeti Fejlesztési Ügynökség és a Közreműködő Szervezetek közötti elszámolások felülvizsgálatának összefoglaló jelentése. [Summary report regarding the audit of the clearing between the National Development Agency and the Intermediary Bodies.]

Blazek, J., \& Vozáb, J. (2006). Ex-ante evaluation in the new member states: the case of the Czech Republic. Regional Studies, 40(2), 237-248.

Cooke, P., \& Laurentis, C. D. (2010). Trends and drivers of knowledge economy. P. Cooke, C. D. Laurentis, C. Collinge, \& S. Macneill (Eds.), Platforms of Innovation: Dynamics of New Industrial Knowledge Flows (pp. 1-26). London: Edward Elgar.

Crevoisier, O., \& Jeannerat, H. (2009). Territorial knowledge dynamics: from the proximity paradigm to multi-location milieus. European Planning Studies, 17(8), 1223-1232.

Dabrowski, M. (2013). EU cohesion policy, horizontal partnership and the patterns of subnational governance: Insights from Central and Eastern Europe. European Urban and Regional Studies, 21(4), 364-383.

EGTC (2009). The European Grouping of Territorial Cooperation (EGTC): state of play and prospects [Pdf]. Retrieved from http://cor.europa.eu/en/documentation/studies/Documents/EGTC-state-of-play/EGTCstate_of_play_and_prospects_EN.pdf

Gordos, T. (2009). A területfejlesztés intézményrendszerének és eszközeinek fejlődése és problémái, régiós szemszögböl. In: Falu, Város, Régió 2009(3), 88-92.

Halkier, H., \& Danson, M. (1996). Regional Development Agencies in Western Europe: A Survey of Key Characteristics and Trends. Aalborg University: Department of History, International and Social Studies, Aalborg University.

Halkier, H., Danson, M., \& Damborg, C. (1998). Regional Development agencies in Europe (pp. 13-25). London: Jessica Kingsley Publishers, Regional Policy and Development Series No. 21.

Halkier, H., Danson, M., \& Bellini, N. (2012). Regional Development agencies: towards a new generation? In Bellini, N., Danson, N. \& Halkier, H. (Eds.), Regional Development Agencies: The Next Generation? London: Routledge

Józsa, V. (2016). Regional Processes In Hungary - From Phare To Smart Specialisation, Deturope - The Central European Journal Of Regional Development And Tourism, 8(3), 14-32.

Kirchner, E.J. (1999). Decentralization and Transition in the Visegrad Poland, Hungary, the Czech Republic and Slovakia. Basingstoke: Macmillan; New York: St. Martin's Press.

Kovács, R. (2007). Helyzetjelentés a Közép-Magyarországi Régióról. [Status Report about the Central-Hungary Region). In T. Kaiser, A. Ágh, \& J. Kis-Varga (Eds.), A régiók Magyarországa I. A regionális intézményrendszer körvonalai (pp. 157-218). Budapest: MTA Szociológiai Kutatóintézet.

Miniszterelnöki Hivatal (2003). Ex-ante értékelés - Regionális Fejlesztési Program 20042006. [Ex-ante evaluation of the Regional Development Programme 2004-2006] Budapest: Nemzeti Területfejlesztési Hivatal. Retrieved from www.nefmi.gov.hu/download.php?docID $=290$

Nagyházi, G. (2015). Regional development trends and the regional development institutions in the Visegrad countries - enabling or hindering institutional environment? DETUROPE, 7(2), 28-44.

Nemec, J., \& Matejová, L. (2014). Decentralisation and Quality of Governance: Selected Issues from the Czech and Slovak Republic. BULLETIN OF TARAS SHEVCHENKO 
NATIONAL UNIVERSITY OF KYIV. ECONOMICS, Kyjev: Taras Shevchenko National University of Kyiv. Neuveden, 26-33.

Nemzeti Fejlesztési és Gazdasági Minisztérium (2009). A hazai területfejlesztési és támogatási rendszer átfogó értékelése (1996-2008). [Comprehensive evaluation of the domestic territorial development system (1996-2008.] Budapest: NFGM.

Palermo, F., \& Parolari, S. (2013). Regional Dynamics in Central and Eastern Europe, New Approaches to Decentralization. Leiden, Boston. Martinus Nijhoff Publishers. ISBN: 978-90-04-24231-9 (e-book)

Pálmai, É. (2014). Evaluation of using EU funding sources in the Regional Operative Programmes DETUROPE, 6(3), 85-96.

Pálné Kovács, I. (2003). A területfejlesztés irányitása. [The governance of territorial development.] Pécs: Pécsi Tudományegyetem Közgazdaság-tudományi Kar, Regionális Politika és Gazdaságtan Doktori Iskola.

Pálné Kovács, I. (2015). AER Study on the state of regionalism in Europe. Country report on Hungary. Pécs: Institute for Regional Studies.

Pálné Kovács, I. (2016). A magyar területi közigazgatási reformok főbb állomásai. [Major milestones of the Hungarian public administrative reform.] In I. Pálné Kovács (Ed.), $A$ magyar decentralizáció kudarca nyomában (pp. 73-85). Pécs: Dialóg Campus Kiadó.

Rechnitzer, J. (2012). A területi politika és az új állam. [The territorial policy and the new state.] MRTT conference, Győr.

Yoder, J. A. (2003). Decentralisation and Regionalisation after Communism: Administrative and Territorial Reform in Poland and the Czech Republic. Europe Asia Studies, 55(2), 263-286. 